\title{
Estetiska uttrycksformer - syskon eller kusiner?
}

Eva Österlind

\section{Estetiska lärprocesser}

Estetiska lärprocesser är en term som syftar på att ett särskilt lärande uppstår i undervisning som involverar estetiska inslag, i form av estetiska ämnen eller uttrycksformer och konstnärliga arbetssätt. ${ }^{\mathrm{I}}$ Det har gjorts åtskilliga försök att definiera begreppet och beskriva vad en estetisk lärprocess skulle kunna vara. ${ }^{2}$ Alla försök i den riktningen görs i relation till, och alltför ofta med ett avståndstagande från, vad som betecknas som vanlig eller traditionell undervisning. ${ }^{3}$ Den så kallade vanliga undervisningen beskrivs något förenklat som fokuserad på lärande av fakta genom verbala och matematiska symboler, ${ }^{4}$ och kontrasteras mot synsättet att estetisk erfarenhet, eller med Deweys ord aesthetic experience, ${ }^{5}$ kan bidra till en mer holistisk förståelse av komplexa fenomen.

En metastudie av estetiska ämnens eventuella transfer effects, alltså om det eleverna lärt sig kan vara användbart i andra (ämnes-) sammanhang, visar på sådana effekter av drama och musik. ${ }^{6}$ Det är dock inte självklart att estetiska ämnen eller lärprocesser alltid är av godo. ${ }^{7}$ Enligt Bamford bidrar estetiska ämnen och inslag i undervisningen till elevers lärande, men bara under förutsättning att de håller hög kvalitet. ${ }^{8}$ Dunn och Stinson varnar för att estetiska inslag kan bli rent funktionella och inte alls bidrar till att höja undervisningens kvalitet. För att lyckas krävs enligt Dunn och Stinson framför allt att pedagogen har ämnesspecifik estetisk kompetens, $\mathrm{i}$ annat fall är det risk att 'the teaching becomes artless'. ${ }^{9}$

Hur du refererar till det här kapitlet:

Österlind, E. 20I8. Estetiska uttrycksformer - syskon eller kusiner? I: von Schantz, U., Thorgersen, K. and Lidén, A. (red.) De estetiska ämnenas didaktik Utmaningar, processer och protester. Pp. 45-66. Stockholm: Stockholm University Press. DOI: https://doi.org/Io.I6993/bap.c. License: CC-BY 
Lindström har konstruerat en modell för att klargöra vad estetiska lärprocesser kan innebära. ${ }^{10}$ Modellen inkluderar både lärande i estetiska ämnen och lärande i andra ämnen via estetiska inslag. Lindström menar att estetiska lärprocesser innefattar fyra olika aspekter - lärande i, om, med och genom olika konstformer - vilket visar att begreppet är flerdimensionellt och mångtydigt. Mångtydigheten framträder i än högre grad genom

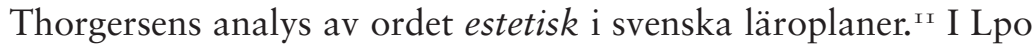
94 användes ordet estetisk på åtta olika sätt i läroplanen, vilket enligt Thorgersen gjorde det svårtolkat för alla som försökte förstå det i ett specifikt sammanhang. För att precisera innebörden av estetisk verksamhet har Marner utvecklat begreppen mediespecifik och medieneutral, som beskriver två olika sätt att se på estetikens roll och betydelse i skolan. ${ }^{\mathrm{I} 2}$ Marner är kritisk till ett medieneutralt synsätt som inte respekterar (kunnande i) de olika konstformerna i sin egen rätt. Problemen med ett medieneutralt synsätt kan beskrivas i relation till multimodal teori. ${ }^{\mathrm{I3}}$

En central utgångspunkt i multimodal teori är att olika modaliteter verkar för att möta olika kommunikationsbehov, och att skilda modaliteter inte är utbytbara eftersom ett och samma budskap inte kan medieras genom olika modaliteter. Budskapet påverkas eller formas ofrånkomligen av den valda modaliteten. Detta är också Marners argument, när han varnar för ett generellt synsätt på estetisk verksamhet där alla modaliteter eller uttrycksformer knutna till olika konstformer buntas ihop till något 'estetiskt', och sedan betraktas som om de har en och samma funktion och roll i elevers lärande. Även om olika modaliteter och estetiska uttrycksformer kan tjäna likartade syften, exempelvis ge existentiella upplevelser eller erbjuda förståelse av komplexa fenomen, kommer innebörden som skapas genom en viss uttrycksform alltid att vara annorlunda än om en annan modalitet hade använts. Därför är det viktigt, enligt Marner, att elever får möjlighet att tillägna sig mediespecifik kunskap och erfarenhet för att kunna kommunicera genom estetiska uttrycksformer på ett kompetent och reflekterande sätt. ${ }^{\mathrm{I}}$

Ur ett internationellt perspektiv kan diskussionen om estetiska lärprocesser förefalla märklig, eftersom begreppet inte har någon direkt motsvarighet i andra länder. Enligt Lindström kan 
det närmast kopplas till begrepp som arts in school och arts education. ${ }^{\mathrm{I}}$ Men behovet att klargöra det estetiska ämnesområdets innehåll och avgränsningar mot andra ämnesområden är inte unikt för Sverige. Undervisning i estetiska ämnen, liksom estetiska inslag i undervisning inom andra skolämnen, samt samverkan mellan olika estetiska ämnen och uttrycksformer, visar på områdets bredd och komplexitet, och därmed behovet av mer preciserade begrepp. I läroplanen för den svenska förskolan används estetiska uttrycksformer. ${ }^{16}$ I grundskolans läroplan talas om de estetiska kunskapsområdena. ${ }^{17}$ På gymnasiet användes tidigare begreppet Estetisk verksamhet som benämning på en kärnämneskurs, obligatorisk för alla elever oavsett program. Sedan 20I I används istället beteckningen Estetisk kommunikation på en valbar kurs, obligatorisk enbart för elever på estetiska programmet.

Läroplanen för grundskolan lyfter fram olika uttrycksformer, och att exempelvis drama ska vara ett inslag i skolans verksamhet..$^{18}$ Trots det har drama fått minskat utrymme i de kursplaner som i hög grad styr undervisningen. ${ }^{19}$ Läroplanen påverkar i sin tur hur det estetiska ämnesområdet organiseras och behandlas inom lärarutbildningen, där utrymmet för såväl estetiska ämnen som estetiska lärprocesser i andra ämnen minskat kraftigt under senare år. Dessa tendenser i grundskolans läroplan och lärarutbildningen, liksom i viss mån reformer inom gymnasieskolan, utgör en bakgrund och ett motiv till föreliggande studie.

I gymnasieskolan behandlas estetiska uttrycksformer i huvudsak som självständiga ämnen. På estetiska programmet utgör undervisning inom ett specifikt estetiskt ämnesområde ca 40-50\% av all undervisning, vilket innebär mer än ett helt skolår. ${ }^{20}$ Detta bedömdes som en möjlig utgångspunkt för att kasta ljus över estetiska ämnen i relation till estetiska lärprocesser, trots att estetiska lärprocesser inte förekommer som begrepp i gymnasiet. Skälet är att elever på estetiska programmet tack vare omfattande undervisning har goda möjligheter att utveckla förtrogenhet inom området. Studien bygger på enkäter till tredjeårselever på estetiska programmets Bild-, Musik- och Teater-inriktningar. Finns det stora likheter i hur eleverna upplever sina respektive estetiska ämnen eller dominerar olikheterna? Finns det fog för att 
sammanföra 'det estetiska' eller inte - i vilken grad är det estetiska kunskapsområdet mediespecifikt eller medieneutralt?

\section{Gymnasieskolans estetiska program}

Den svenska gymnasieskolan är organiserad i ett antal studieprogram som är inriktade mot olika kunskapsområden. Varje program består av en specifik ämneskombination med ett antal givna och några valbara kurser. Inom ett studieprogram är flertalet kurser obligatoriska, vilket betyder att programvalet får stor betydelse för utbildningens innehåll.

Estetiska programmet, som introducerades I994, visade sig bli ett av de mest populära och därmed ett av de största studieprogrammen. ${ }^{2 I}$ I samband med att gymnasieskolan reformerades föreslogs att Estetiska programmet skulle breddas till 'Estetik och Humaniora' och innehålla en kombination av estetiska ämnen och språk. ${ }^{22}$ Ett annat förslag var att kursen 'Estetisk verksamhet' inte längre skulle vara en kärnämneskurs för alla elever. Dessa förslag utsattes för hård kritik, vilket ledde till att Estetiska programmet fick vara kvar. Kursen 'Estetisk verksamhet' ströks däremot, trots att det även enligt den nya läroplanen Gy 20 I I är 'skolans ansvar att varje elev kan hämta stimulans ur kulturella upplevelser och utveckla känsla för estetiska värden'.23 I en utredning från 2016 dryftas dock återinförandet av ett estetiskt ämne på samtliga program. ${ }^{24}$

Enligt de nuvarande examensmålen är estetiska programmet ett högskoleförberedande program: 'Efter examen från programmet ska eleverna ha kunskaper för högskolestudier inom främst de konstnärliga, humanistiska och samhällsvetenskapliga områdena'. ${ }^{25}$ Syftet beskrivs i läroplanen som att 'utveckla elevernas kunskaper i och om de estetiska uttrycksformerna'. ${ }^{26}$ Eleverna ska få möjlighet att 'skapa, uppleva och tolka konst och kultur'. ${ }^{27}$ De ska även få 'allsidig träning i det estetiska hantverket', och 'utveckla sin analytiska förmåga'. ${ }^{28}$ Eleverna ska också lära sig 'att kommunicera tankar och idéer med estetiska uttrycksmedel'. ${ }^{29}$ 'Kreativitet, nyfikenhet, kommunikation, samspel samt förmåga till eget skapande och framförande ska vara centralt $\mathrm{i}$ utbildningen'..$^{\circ}$ 
Estetiska programmet har fem grenar, bild och formgivning, dans, estetik och media, musik samt teater ${ }^{3{ }^{3}}$ Eleverna väljer en av dessa inriktningar, och behåller den under hela gymnasietiden. I allmänhet är elevgrupperna blandade, med varierande bakgrundsförhållanden. En majoritet, $66 \%$ av eleverna på det estetiska programmet är flickor, men pojkar dominerar musikinriktningen..$^{32}$ Många gymnasieskolor kan anta alla behöriga sökande men i vissa fall, om många elever söker till en specifik skola, kan urval göras utifrån betyg och/eller antagningsprov.

\section{Studiens syfte och genomförande}

Syftet är att beskriva gymnasieelevers erfarenheter och uppfattningar av tre karaktärsämnen inom Estetiska programmet, nämligen bild och formgivning, musik och teater, som utgångspunkt för att belysa frågan om estetiska uttrycksformer i huvudsak är likartade eller olikartade.

Datamaterialet består av enkäter till ett sjuttiotal elever. Frågeformuläret, som ursprungligen konstruerades av McCammon, ${ }^{33}$ har bearbetats något för att passa svenska förhållanden. Resultat rörande de svenska teatereleverna har presenterats av Österlind, ${ }^{34}$ liksom en jämförelse mellan teaterelever från Arizona och Sverige som påvisade stora likheter. ${ }^{35}$ Teaterelevernas upplevelser och erfarenheter är alltså relativt väl genomlysta. ${ }^{36}$ Studien om teater kompletterades senare med motsvarande enkäter till elever som valt bild och formgivning, samt musik. Eftersom det rör sig om en undersökning i liten skala går det inte att dra några generella slutsatser av resultaten.

En av skolorna är belägen i Stockholms innerstad, men tillhör inte någon av de mest välkända gymnasieskolorna. Den andra skolan ligger i en mindre stad i Mellansverige. Båda skolorna erbjuder ett brett urval av studie- och yrkesförberedande program, och det är rimligt att anta att båda skolorna tar emot elever med varierande social bakgrund. De två skolorna, lärarna och elevgrupperna var inledningsvis helt okända för mig, och valdes utan någon kännedom om förutsättningarna på respektive skola. Det är inte heller känt $\mathrm{i}$ vilken mån man samverkade över ämnesgränserna mellan de olika estetiska inriktningarna, på de båda skolorna. 
Frågeformuläret inleds med bakgrundsinformation följt av sex öppna frågor om respektive ämne, här med exemplet teater. I. Varför bestämde du dig för att välja Estetiska programmet med inriktning teater? 2. Beskriv kort några av de saker du deltagit i som elev på teaterprogrammet. 3. Vad är mest utmanande med att gå teaterprogrammet? 4 . Beskriv din mest minnesvärda teaterupplevelse. 5. Tror du att din teatererfarenhet från gymnasiet kommer att påverka dig i framtiden? I så fall, förklara kortfattat hur. 6 . Skulle du rekommendera andra att gå en teaterkurs eller vara med i teaterprojekt på din skola, eller gå det estetiska programmet med inriktning teater? Varför eller varför inte?

Eleverna fick information om att enkäten genomfördes i forskningssyfte och att ingen utom forskaren skulle ha tillgång till deras svar. Ingen skulle heller kunna identifieras, även om enstaka enkätsvar citerades. Eleverna fick också veta att det var frivilligt att medverka, och att de kunde välja att hoppa över frågor - även om det naturligtvis var önskvärt att alla frågor besvarades. ${ }^{37}$ Samtliga elever gick sitt tredje och sista år på estetiska programmet, men teatereleverna svarade sent på hösten, medan övriga elever svarade i slutet av våren, vilket innebar att teatereleverna inte hunnit lika långt i sin utbildning. För teater medverkade 30 elever. För bild deltog 2 I elever och för musik svarade 17 elever. Sammanlagt har 68 elever, 50 flickor och 16 pojkar, samt två elever som valt att inte angett kön, besvarat enkäten (se Tabell I).

\section{Fenomenografi}

Fenomenografi utgör en ram för analysen av teaterelevernas svar. Fenomenografin utvecklades av Marton tillsammans med en

Tabell 1. Elever som deltog i studien

\begin{tabular}{lcccc}
\hline & Bild \& form & Musik & Teater & Totalt \\
\hline Flickor & I 5 & IO & 25 & 50 \\
Pojkar & 5 & 6 & 5 & I6 \\
Ej svarat & I & I & - & 2 \\
Totalt & 2I & I7 & 30 & 68 \\
\hline
\end{tabular}


grupp svenska forskare, för att beskriva variationen i studenters uppfattningar av ett givet fenomen. ${ }^{3}{ }^{8}$ Baserat på data, vanligtvis från intervjuer, konstrueras kvalitativt skilda uppfattningar av det studerade fenomenet. Fenomenografi liksom fenomenologi fokuserar på hur människor erfar sin omvärld, men de skiljer sig åt beträffande syfte och metod. ${ }^{39}$ Fenomenologin strävar efter att beskriva essensen eller kärnan i ett visst fenomen, medan fenomenografin strävar efter att beskriva variationen i hur ett fenomen uppfattas och förstås. 'The aim ... is not to find the singular essence, but the variation and the architecture of this variation'. $4^{\circ}$

Ett betydelsefullt kännetecken är att en fenomenografisk analys utgår från datamaterialet och inte från i förväg konstruerade beskrivningskategorier. Avsikten är att nå bortom individuella yttranden och söka underliggande mönster i materialet som helhet, och utifrån detta formulera ett fåtal, kvalitativt skilda uppfattningar av det studerade fenomenet. Vanligen väljs citat ur materialet för att illustrera beskrivningskategorierna. Kategorierna presenteras sedan i relation till varandra i ett utfallsrum.

Traditional phenomenographic research aims to investigate the qualitatively different ways in which people understand a particular phenomenon or an aspect of the world around them. These 'different ways of under-standing', or conceptions, are typically represented in the form of categories of description, which are further analysed with regard to their logical relations in forming an outcome space. ${ }^{4 \mathrm{I}}$

För att kunna genomföra en fenomenografisk analys krävs ett rikt och fylligt datamaterial. Det kan samlas in genom enkäter, men intervjuer är vanligtvis att föredra. I den här studien är de skrivna svaren ibland kortfattade, och en fenomenografisk analys av hela datamaterialet har inte varit möjlig att genomföra (mer om detta nedan). Inledningsvis presenteras en sammanfattning av datamaterialet ämne för ämne, knuten till enkätfrågorna. Detta följs av en kortfattad beskrivning av de kategorier som var resultatet av den tidigare genomförda fenomenografiska analysen av enkätsvaren om teater. ${ }^{42}$ Värt att notera är att i en renodlad fenomenografisk analys har antalet respondenter som uttrycker en viss 
uppfattning ingen betydelse, det viktiga är att formulera variationen av uppfattningar bland deltagarna. I det här sammanhanget är det dock av intresse att se hur vanlig eller ovanlig en viss uppfattning är i de olika elevgrupperna. Därför avslutas resultatdelen med ett avsnitt där enkätsvaren från de olika ämnesinriktningarna jämförs med varandra.

\section{Elevernas erfarenheter}

När datamaterialet granskades i sin helhet framkom en påtaglig skillnad mellan enkätsvaren, som bestod av att bildeleverna hade svarat relativt kortfattat, medan musik- och teatereleverna hade svarat mer utförligt. Svaren på musik- och teaterenkäterna var dubbelt så omfattande och rika på detaljer. Skillnaden var synlig med blotta ögat och lätt att kontrollera (se Tabell 2).43 Att bildeleverna svarat så korthugget gjorde det omöjligt att genomföra en fenomenografisk analys. ${ }^{44}$ Detta avsnitt bygger därför på en kombination av kvalitativa och kvantitativa beskrivningar av datamaterialet. Först presenteras ämnena var för sig. Därefter presenteras resultatet av den fenomenografiska analysen av teaterelevernas erfarenheter i form av sju beskrivningskategorier. Avslutningsvis relateras analysen av teater till enkätsvaren om bild och musik.

\section{Bild och Form}

Motiven till att välja Estetiska programmet - bild och formgivning, är knutna till ett starkt intresse; 'bild har alltid varit mitt liv' $\left(\mathrm{B}_{5}\right)^{45}$, 'det är roligt att vara kreativ' (BI8) och man träffar 'roligt folk' (B3). Ett par av eleverna visste redan när de valde bild och formgivning att de ville yrkesarbeta inom området. Några nämner brist på

Tabell 2. Enkätsvar, omfattning och bortfall

\begin{tabular}{lrrrl}
\hline & $\begin{array}{l}\text { Bild \& } \\
\text { form }\end{array}$ & Musik & Teater & \\
\hline Antal ord & I77I & 2752 & 4620 & Totalt 9I43 ord \\
Antal ord i medeltal & 84 & I62 & I54 & M = I34 ord \\
Obesvarade frågor & 5 & I & 2 & \\
\hline
\end{tabular}


motivation för andra skolämnen och att 'jag ville göra något roligt under skoltiden inte bara teori' (B I7). En elev skriver att hen aldrig skulle klara NV- eller S-programmet. När bildeleverna besvarar övriga enkätfrågor, till exempel vad de deltagit $i$, domineras deras svar av referenser till material och tekniker, 'jag har målat med olja, akryl, huggit i trä och jobbat med lera’ (B 8). Detta är mycket vanligt förekommande i svaren på fyra av de sex enkätfrågorna. Exempelvis nämner bara en enda elev besök på konstmuséer under utbildningen, trots att sannolikt alla elever deltagit. Därnäst lyfter bildeleverna fram problem i generella termer, relaterade till kreativitet och (brist på) inspiration. Även utmaningar som uttrycks i allmänna ordalag, 'att alltid vara kreativ' ( $\mathrm{B}_{\mathrm{I}_{3}}$ ), och 'toppa sig själv med varje uppgift' (B4), tycks vara nära knutna till material och verktyg. På frågan om bild- och formstudierna kommer att påverka dem $\mathrm{i}$ framtiden, är det endast ett fåtal svar som går bortom bildoch formundervisningen i sig, och antyder att det eleverna lärt sig kan vara användbart i andra sammanhang, till exempel: 'man måste kolla på saker i ett annat perspektiv och nu gör man de[t] utan att tänka' (B9). En elev 'har mest utvecklats som person och blivit mer säker' (B I 5). 'Ja, man blir mer kreativ inom alla områdena i livet. Man har en längtan efter kreativitet.' (BI7). Nästan alla elever, I 8 av 2 I, skulle rekommendera andra att välja Bild- och formprogrammet eftersom de har lärt sig mycket, men sex elever skriver att de inte skulle rekommendera sin egen gymnasieskola.

\section{Musik}

Eleverna är mycket entusiastiska över Estetiska programmet musik. Deras motiv är i huvudsak knutna till ett livligt intresse för musik; 'Jag blir aldrig mätt /.../ ger mig en känsla av egenvärde' (MI4). Många ville göra något kul och 'jag förstod att det var [det] som gjorde mig lycklig' (MI I). Fyra elever skriver att de var skoltrötta, 'Jag ville studera något som jag verkligen var intresserad av, för att få mer studiemotivation’ (MI6). I beskrivningarna av vad de gjort i musikämnet domineras svaren av hänvisningar till konserter av olika slag som de genomfört under gymnasietiden. De nämner också individuella lektioner på det egna instrumentet samt musikteori. Eleverna skriver att de har lärt sig mycket, exempelvis att komponera, att arrangera konserter, att stå på scenen, 
och att nå en publik. Musikteori sägs vara det mest krävande, den beskrivs som 'klurig och svår' $\left(\mathrm{M}_{3}\right)$. Det kan också vara en utmaning att arbeta tillsammans, att organisera repetitioner med mera, något som gäller såväl kammarmusik som rockband.

Det mest utmanande är nog att komma överens inom klassen /.../ de flesta har mycket starka viljor, särskilt när det kommer till musik /.../ Men vi har genom musiken lärt att arbeta mycket bra i grupp (M2).

Några elever nämner mer generella kompetenser som de har erövrat, som att planera, att samarbeta, att våga ta initiativ, att utsätta sig och riskera att misslyckas. Den överlägset mest minnesvärda musikupplevelsen är den avslutande konserten, musikshowen som de genomförde bara några veckor innan de besvarade enkäten. Alla musikelever utom en är beredda att rekommendera musikprogrammet till andra elever, för någon är det 'de enda 3 lyckliga åren under hela min skoltid' (MI4). Skälen till det hänger i första hand ihop med vad de har lärt sig och hur mycket de har utvecklats som musiker. Även samarbetsförmåga, personlig utveckling och de nära relationer som växer fram när man musicerar och uppträder tillsammans, lyfts fram. Två tredjedelar av musikeleverna refererar minst en gång till grupparbete, personlig utveckling och en stark känsla av samhörighet, men några nämner också vissa förutsättningar 'jag tror inte att man kan gå en roligare gymnasieutbildning än estet-musik. Men man måste vara intresserad och engagerad och ha en del kunskap...' ( M2).

\section{Teater}

Eleverna som valt Estetiska programmet - teater, är uttalat positiva, men deras svar har olika känslomässig ton. Vissa elever är passionerade, de skriver t.ex. att de 'älskar att spela teater' (TI). Andra elever är genuint positiva, och hänvisar till att teater är 'intressant' och 'kul' ( $\left.\mathrm{T}_{3}\right)$. Ytterligare andra svar är positiva, men mer återhållsamma; 'teater verkade roligt' (T6). Enstaka svar är mer distanserade, och har en kritisk eller negativ ton. Kritiken handlar om att antingen ha 'fått nog' av teater, eller att inte ha fått tillräckligt av 'riktig teater' under studietiden. Endast en elev är 
negativ till studieprogrammet, på grund av 'meningslösa småprojekt' (Tıо). Flertalet av eleverna hade redan viss eller omfattande erfarenhet av teater när de gjorde sitt programval. En elev nämner det som en förutsättning för att bli nöjd med sitt val. Teater sägs skapa en väldigt speciell, positiv stämning och närhet mellan studenterna: 'Teater är lika med gemenskap' (T29), och man kan 'se klasskompisar utvecklas' (T22). Kompetenser som växer fram under teaterlektionerna kan vara användbara i många andra sammanhang. Att 'prata högt och tydligt inför grupp /.../använda kroppsspråket på ett helt annat sätt' (T26), och 'ha förmågan att se och hitta nya lösningar på problem som uppstår' (T27) nämns av eleverna. Sådana förmågor kan vara 'användbart inom fler branscher än teater' (T24), och 'i alla relationer och sociala sammanhang' (T 25). Teater är 'underskattat' ( $\mathrm{T}_{5}$ ) och 'lärorikt som attan' ( $\left.\mathrm{T}_{7}\right)$. 'Bara för att det vi gör här är fiktivt, betyder [det] inte att man inte har användning av det i det i verkliga livet' (T8).

Den fenomenografiska analysen av teaterelevernas enkätsvar, som genomfördes separat, resulterade i sju beskrivningskategorier relaterade till varandra i ett utfallsrum (jfr Österlind, 20I I). Kategorierna beskriver dels uppfattningar av teaterämnet i sig, dels teater i relation till andra skolämnen. När det gäller teaterämnet i sig, och vad man faktiskt lär sig, beskrivs några olika aspekter (se Figur I). Teaterstudier kan vara en källa till personlig utveckling, 'man får en helt ny kännedom om sig själv' (T2) och blir mer social och ‘öppen som person' (T28). De kan leda till utveckling av ämnesspecifika förmågor som 'konsten att agera' (T20) och utveckling av generella kompetenser som att 'tala framför publik' (T24). Men teaterstudierna kan också uppfattas som inte tillräckligt utmanande, 'vill man satsa på teater är det här fel skola' (Tıо).

När teaterämnet jämförs med andra skolämnen (se Figur 2) framhålls teater som en källa till vänskap och glädje, 'det är roligt och givande' (T24), 'man får en helt annan samhörighet med sin klass’ (T2). Ämnet kan motverka skoltrötthet och bidra till ökad motivation; 'jag hade nog varit enormt skoltrött redan i I:an om det inte hade varit för teaterlektionerna' (T26). Men det kan också bli för mycket av det goda, när teater är något man uppskattar men får i lite för stor dos på estetiska programmet så 'att man efter tre år känner att teater inte är roligt längre /.../ man tröttnar.' (T28). 


\section{Teaterämnet och lärande}

\begin{tabular}{|l|l|l|l|}
\hline Teater som & Teater som & Teater som & Teater som \\
personlig & ämnesspecifika & generella & inte tillräckligt \\
utveckling & förmågor & kompetenser & utmanande \\
\hline
\end{tabular}

Figur 1. Elevernas upplevelser av lärande i teaterämnet

\section{Teater jämfört med andra ämnen}

\begin{tabular}{|l|l|l|}
\hline $\begin{array}{l}\text { Teater som } \\
\text { källa till glädje } \\
\text { och vänskap }\end{array}$ & $\begin{array}{l}\text { Teater som } \\
\text { botemedel mot } \\
\text { skoltrötthet }\end{array}$ & $\begin{array}{l}\text { Teater som } \\
\text { för mycket } \\
\text { av det goda }\end{array}$ \\
\hline
\end{tabular}

Figur 2. Elevernas erfarenheter av teater i relation till andra skolämnen

\section{Sammanfattning}

Resultatet av den fenomenografiska analysen, de sju kategorierna som beskriver elevernas uppfattningar av teater, har relevans även för enkätsvaren om bild och musik. Två av kategorierna, där eleverna uppfattar ambitionsnivån som alltför låg respektive för hög, representeras av ett par teaterelever. Ingen bild- eller musikelev har beskrivit sina studier som inte tillräckligt utmanande. Däremot finns en elev som uttrycker en liknande uppfattning av bildämnet, att det kan bli för mycket av det goda, 'det är inte roligt längre' (B2). Erfarenheter som stämmer överens med de övriga fem beskrivningskategorierna, det vill säga personlig utveckling, ämnesspecifika förmågor, generella kompetenser, glädje och vänskap, samt bot mot skoltrötthet, finns representerade även i bildoch musikelevernas enkätsvar.

Men det finns också intressanta skillnader, bland annat relaterade till antalet svar av en viss typ. Innan vi går in på dem vill jag påminna om att det handlar om ett begränsat material, och att det inte går att dra några slutsatser annat än för just de elevgrupper 
som deltagit i studien. När vi börjar granska enkätsvaren i termer av antal och proportioner, och jämföra olika elevgrupper sinsemellan, lämnar vi också fenomenografins domäner.

Det finns stora skillnader i mål och ambitionsnivå mellan eleverna inom alla ämnesgrupper, som lite tillspetsat handlar om att en del valt något de brinner för medan andra valt bort något de vill slippa. Vissa elever vill bli professionella och arbeta inom sin konstform, medan andra inte alls har det som mål - att välja estetiska programmet som botemedel mot skoltrötthet nämns av några elever inom varje ämnesgrupp. Detta tycks dock inte orsaka några nämnvärda konflikter mellan eleverna. I stort sett samtliga elever säger att de har lärt sig väldigt mycket, och blivit skickligare i sina ämnen. Det är

förväntat efter tre års studier, och här finns ingen tydlig skillnad mellan ämnesgrupperna. Det stora flertalet av eleverna skulle gärna rekommendera sitt studieprogram till andra, även om entusiasmen är något mer dämpad bland bildeleverna. Några elever nämner att ett seriöst intresse och förkunskaper är en förutsättning för att bli nöjd med sitt val.

Estetiska ämnen som källa till vänskap och glädje påtalas också i samtliga ämnesgrupper, men av ett fåtal elever i bildgruppen och av en stor majoritet i musik- och teaterklasserna. Teatereleverna skriver betydligt mer, och på ett mer detaljerat och reflekterande sätt än de övriga, när det gäller personlig utveckling och generella kompetenser och de lyfter i högre grad fram kunnandet som allmängiltigt. Två tredjedelar av musikeleverna tar också upp personlig utveckling och generella kompetenser, som att lära sig samarbeta, men främst i relation till musikutövning. Bland bildeleverna nämns dessa två aspekter endast av en student vardera. Musik- och teatereleverna beskriver alltså mer likartade erfarenheter. Det är på de här punkterna, personlig utveckling och generella kompetenser, som svaren tydligast skiljer sig åt mellan grupperna.

Vad kan vi eventuellt få ut av dessa likheter och skillnader? En närmast banal slutsats är att elevernas upplevelser och uppfattningar ser ut att vara nära kopplade till respektive ämne. Bildeleverna refererar bara undantagsvis till det omgivande samhället, utanför konstfältet eller bildklassrummet. Musikeleverna 
har varit orienterade mot konserter och att möta publik av olika slag, och lyfter fram att de därigenom utvecklat generella kompetenser som samarbetsförmåga. I det begränsade datamaterialet framträder sådana transfer-effekter allra tydligast i relation till teater. Ett stort antal elever framhåller att de genom teaterämnet utvecklat generella kompetenser som de pekar ut som värdefulla för många olika sociala situationer och yrkesområden.

\section{Avslutande reflektioner}

Estetiska programmet är värdefullt på många sätt enligt de elever som deltagit i studien. Det är inte så många elever som valt det för att övervinna sin skoltrötthet, men även ett fåtal elever som tack vare det estetiska programmet lyckas fullfölja sina gymnasiestudier är en stor framgång. Särskilt musik- och teatereleverna lyfter fram att de lärt sig samarbeta och blivit mer frimodiga. I samtliga ämnen utvecklar man sin kreativa förmåga och lär sig att lösa problem. Dessutom har givetvis de estetiska ämnena, precis som alla andra skolämnen, ett inneboende värde.

Att eleverna har olika ambitionsnivå nämns inte som ett problem, vilket är intressant ur pedagogisk synvinkel eftersom olika mål och ambitioner skulle kunna utgöra en källa till konflikter. ${ }^{46}$ Att estetiska programmet faktiskt har motiverat skoltrötta elever att fullfölja gymnasiet är högst intressant eftersom avhopp från gymnasiet är ett stort problem, både för individen och för samhället som helhet. Detta faktum förringar inte egenvärdet av estetisk utbildning, men bör inte heller negligeras.

\section{Vad har de estetiska ämnena gemensamt och vad skiljer dem åt?}

Jämfört med andra skolämnen tycks de ge mer utrymme för kreativitet och problemlösning baserad på elevernas egna idéer. Det handlar åtminstone delvis om att förverkliga visioner, inte om att i snäv bemärkelse göra rätt. Det finns definitivt måttstockar även inom estetiska ämnen, men det finns sällan ett facit. Något som bedöms som en felaktighet eller ett misstag kan ofta korrigeras på flera sätt, med olika resultat, och ändå bli 'rätt' eller snarare 'bra'. Utrymmet för - och kraven på - interaktion mellan eleverna, produktion och samarbete i skarpt läge, exempelvis i samband 
med framträdanden inför publik, speciellt inom musik och teater, utgör sannolikt en positiv drivkraft $i$ arbetet.

De estetiska ämnena går utöver verbal och skriftlig kommunikation. Eleverna är inte enbart hänvisade till att läsa och skriva. De kroppsliga och materiella aspekterna är nära knutna till hantverksskicklighet, omdömesförmåga och handens kunnande. Processen kännetecknas av att finna kreativa lösningar på olika typer av problem. (De måste vara kreativa eftersom de specifika problem som uppstår ytterst sällan är upprepningar av andra problem.) Sådana förutsättningar försöker man ibland konstruera, t.ex. inom entreprenöriellt lärande, men här uppstår både problemen och motivationen att lösa dem så att säga av sig själva, i ett givet sammanhang.

I skapandet av bild, musik och teater involveras i regel kropp och sinnen på ett högst påtagligt vis. Jag vill hävda att det råder en bättre balans mellan tankar, känslor, intuition, intention och aktion, inom de estetiska ämnena. För att inte tala om kroppen, som istället för att negligeras tas på fullt allvar. De estetiska ämnena upplevs också som meningsfulla av i stort sett alla studenter i studien..$^{4748}$ I bästa fall handlar det om bildning som involverar hela människan.

Utifrån den här småskaliga studien innebär bildämnet att eleverna i hög utsträckning fokuserar på material, redskap och tekniker. Musik bygger också på att lära sig specifika tekniker, men i det här fallet tycks själva musicerandet, tillsammans och inför en publik, vara det överordnade målet. Då blir det musiken i sig som är den centrala idén eller budskapet, som musikeleverna förmedlar genom personliga tolkningar, uttrycksförmåga och teknisk skicklighet. Av enkätsvaren att döma är teater det estetiska ämne som kommer närmast inpå eleverna som personer. Teater tycks vara den mest utlämnande av dessa tre konstformer, kanske eftersom utövaren använder sig själv som 'instrument'. Som teaterelev agerar man ofta tillsammans, ibland väldigt nära varandra, och använder sig av sin egen kropp och sin personlighet. Teatereleverna är också de som i störst utsträckning betonar en djupgående utveckling av generella kompetenser, som kommunikationsförmåga.

Resultatet visar att det finns en viss samstämmighet i hur eleverna upplever sina ämnen, men också uttalade skillnader som kan 
knytas till de olika ämnena. Samtidigt är det är uppenbart att likheterna inte är försumbara. Två av eleverna, varav en skriver på engelska, svarar så här på frågan om de skulle rekommendera estetiska programmet - musik, till andra elever:

Of course I would recommend it, because everyone in the world listens to or is effected by art and music, so it seems to be the most useful and intellectually enriching [study program] there is (MI 5 ).

Absolut! /.../ Estetmusikprogrammet är fantastiskt bra och roligt. Människorna som går estet är väldigt snälla och roliga människor. Att gå estet har varit mitt livs hittills bästa val (Mı6).

Dessa avslutande citat ger en fingervisning om att trots att dessa gymnasieelever under tre års tid har fördjupat sig inom ett visst estetiskt ämne, ger de uttryck för ett ämnesövergripande synsätt och berikande upplevelser som inte tycks knutna till ett enskilt ämne eller en specifik konstform. Med andra ord, de estetiska ämnena är både 'lika och unika'.49

\section{Estetiska lärprocesser...?}

Estetiska lärprocesser som begrepp och som företeelse har utsatts för kritik från olika håll. Häggström för t.ex. fram uppfattningen att det inte finns några estetiska lärprocesser, utan bara lärprocesser och estetiska processer. ${ }^{\circ}$ Ett annat kritiskt resonemang går ut på att när resurserna minskar lyfts samlingsbegrepp som estetiska lärprocesser fram, som ett sätt att minska utgifterna för lärare med specifik ämneskompetens, särskilda salar och utrustning som kostar pengar. Fyller begreppet estetiska lärprocesser en funktion genom att tydliggöra något väsentligt, som förväntas ingå i undervisningen och som vi behöver kunna tala om? Eller är det så att det, genom sin otydlighet och mångtydighet, skapar oreda och bidrar till att 'späda ut' något som tidigare betraktats som omistlig men nu stundtals behandlas som ett utanverk, en dekoration?

Estetisk erfarenhet kan, enligt Dewey, bidra till en mer holistisk förståelse av komplexa fenomen. ${ }^{5 \mathrm{I}}$ Bamford hävdar att undervisning av hög kvalitet är en helt avgörande förutsättning för elevers lärande genom estetiska inslag. ${ }^{22}$ Detta kräver i sin tur kunniga 
lärare. ${ }^{53}$ Så länge lärarutbildningen inom det estetiska området bedrivs under samlingsnamnet estetiska lärprocesser, och dessa ges synnerligen begränsat utrymme, blir det svårt att uppnå god kvalitet. Det verkar högst sannolikt att för att kunna arbeta med estetiska lärprocesser som inslag i undervisning inom andra ämnesområden - som fördjupning inte som dekoration - behöver pedagogerna mediespecifik kompetens inom ett eller flera estetiska uttryck.

\section{Slutnoter}

I. Törnquist, 20 I I. Estetiska lärprocesser.

2. Se t.ex. Burman, (Red.), 20I4. Konst och lärande - Essäer om estetiska lärprocesser.

3. Häggström, 20I4. Estetiska lärprocesser - ett begrepp som stärker eller marginaliserar?

Thorgersen, 2007. Unspoken truths: about aesthetics in Swedish schools.

4. Lindström, 2009. Estetiska lärprocesser om, i, med och genom slöjd.

Marner, 2008. Estetiska läroprocesser och/eller estetiska ämnen.

5. Dewey, I934/2005. Art as Experience.

6. Winner, Goldstein, \& Vincent-Lancrin, 2013. Art for Art's Sake? The Impact of Arts Education.

7. Veiden, 20I 2. Tiden og den organisert (vel)vilje.

8. Bamford, 2006. The wow factor: global research compendium on the impact of the arts in education.

9. Dunn, \& Stinson, 20II. Not without the art!! The importance of teacher artistry when applying drama as pedagogy for additional language learning, s. 6I7.

I०. Lindström, 2009.

I I. Thorgersen, 2007.

I 2. Marner, 2008. 
I3. Selander, \& Kress, 2010. Design för lärande: ett multimodalt perspektiv.

I4. Marner, 2008.

I 5 . Lindström, 2009.

I6. Skolverket, I998. Läroplan för förskolan, Lpfö 98. Reviderad 2016.

I 7. Skolverket, 20 I I. Läroplan för grundskolan, förskoleklassen och fritidshemmet.

I 8. Skolverket, 20I I.

I9. Österlind, Østern, \& Thorkelsdóttir, 2016. Drama and theatre in a Nordic curriculum perspective - a challenged arts subject used as a learning medium in compulsory education.

20. När undersökningen gjordes var drygt $30 \%$ av innehållet på estetiska programmet kurser i estetiska ämnen.

21. Enligt SOU 201 6:77, En gymnasieutbildning för alla, är Estetiska programmet fortfarande ett av de största studieprogrammen.

22. SOU 2008:27. Framtidsvägen - en reformerad gymnasieskola.

23. Gy 201 I, Läroplan, examensmål och gymnasiegemensamma ämnen för gymnasieskola $201 \mathrm{I}$, s. 9.

24. SOU 20I6:77.

25. Gy 2011 , s. 227.

26. Gy 2011 , s. 227.

27. Gy 2011 , s. 227.

28. Gy 201 I, s. 227.

29. Gy $201 \mathrm{I}$, s. 227.

30. Gy $201 \mathrm{I}$, s. 227.

3I. Gy 2011 , s. 227.

32. Uppgifterna gäller läsåret 20I4/I 5 . http://skolnet.skolverket.se/ polopoly/programblad/20I4/hf/estetiska.pdf

33. McCammon, 2010. 'Everybody has Somewhere they Belong; Luckily for me I Belong in Theatre'. Experienced Secondary Students Reflect on Their Participation in Theatre. 
34. Österlind, 20I r. 'What Theatre is All About'. Students' Experiences of the Swedish Theatre Arts Program.

35. McCammon, \& Österlind, 20 I I. "Drama has given me a home": Perspectives of Experienced Secondary School Drama/Theatre Students in Two Countries.

36. Resultaten stämmer också väl överens med andra svenska studier om drama/teater:

Chaib, I996. Ungdomsteater och personlig utveckling. En pedagogisk analys av ungdomars teaterskapande.

Olsson, 2006. Att vara någon annan. Teater som estetisk läroprocess vid tre 6-9-skolor.

37. Eftersom eleverna var äldre än I 8 år behövde inte elevernas målsmän ge tillstånd till deras medverkan.

38. Marton, I98 I. Phenomenography: Describing conceptions of the world around us.

39. Marton, \& Booth, I997. Learning and awareness.

40. Marton, \& Booth, I997, s. I I 7.

4I. Marton, \& Pong, W. Y. 2005. On the unit of description in phenomenography. s. 335 .

42. För en mer utförlig beskrivning av kategorierna se Österlind, 20 I I.

43. Det påtagliga skillnaden berodde inte på nämnvärda olikheter i könsfördelningen i de olika grupperna.

44. En fenomenografisk analys grundas i regel på djupintervjuer. Även skriftliga svar, t.ex. i enkäter med öppna frågor förekommer, men i det här fallet var det inte meningsfullt ens med en fenomenografiskt 'inspirerad' analys eftersom en del av datamaterialet var så begränsat. Trots det var det givetvis möjligt att utläsa en del information ur samtliga enkäter.

45. Hänvisningarna knyter citat till enskilda enkätsvar, B står för bild, $\mathrm{M}$ för musik och $\mathrm{T}$ för teater.

46. Se Remfeldt, 20 I I. Att kalibrera den teaterpedagogiska kompassen.

47. Dessa resultat är i linje med exempelvis Chaib (I996) och Olsson (2006), som visar den nära kopplingen mellan teaterverksamhet, personlig utveckling och identitet. 
48. Eftersom eleverna frivilligt valt att gå estetiska programmet kan man tycka att detta är självklart. Men att alla gymnasieelever valt ett program och ett karaktärsämne innebär långtifrån alltid att de upplever ämnet som meningsfullt (se Österlind 2008).

49. Uttrycket är lånat från Anita Grünbaums bok «Lika och unika. Dramapedagogik om minoriteter» (Daidalos 2009).

50. Häggström, 20I4.

5I. Dewey I934.

52. Bamford, 2006.

53. Dunn, \& Stinson, 20 I I.

\section{Referenser}

Bamford, A. 2006. The wow factor: global research compendium on the impact of the arts in education. Münster; Waxmann.

Burman, A. (Red.), 20I4. Konst och lärande - Essäer om estetiska lärprocesser. Södertörn Studies in Higher Education 3, Södertörns Högskola.

Chaib, Ch. 1996. Ungdomsteater och personlig utveckling. En pedagogisk analys av ungdomars teaterskapande. Lund: Lunds universitet.

Dewey, J. I934/2005. Art as Experience. NewYork: Perigee.

Dunn, J. \& Stinson, M. 20I I. Not without the art!! The importance of teacher artistry when applying drama as pedagogy for additional language learning. RiDE: The Journal of Applied Theatre and Performance I6(4), 617-633.

Gy 20I I. Läroplan, examensmål och gymnasiegemensamma ämnen för gymnasieskola 20 I I. Skolverket, Stockholm.

Häggström, M. 20I4. Estetiska lärprocesser - ett begrepp som stärker eller marginaliserar? I O. Franck (Red.) Motbok. Kritiska perspektiv på styrdokument, lärarutbildning och skola (s. I 27-I40). Lund: Studentlitteratur.

Lindström, L. 2009. Estetiska lärprocesser om, i, med och genom slöjd. KRUT Kritisk utbildningstidskrift I33/I34, 57-68. Göteborg. 
Marner, A. 2008. Estetiska läroprocesser och/eller estetiska ämnen. KRUT Kritiskutbildningstidskrift I3 I, 5-I 5. Göteborg.

Marton, F. I98I. Phenomenography: Describing conceptions of the world around us. Instructional Science I0, I77-200.

Marton, F. \& Booth, S. I997. Learning and awareness. Mahwah, NJ: Erlbaum.

Marton, F. \& Pong, W. Y. 2005. On the unit of description in phenomenography. Higher Education Research \& Development $24(4), 335-48$.

McCammon, L. 20I0. 'Everybody has Somewhere they Belong; Luckily for me I Belong in Theatre'. Experienced Secondary Students Reflect on Their Participation in Theatre. Drama Research I(I), 88-I06.

McCammon, L. A. \& Österlind, E. 20I I. "Drama has given me a home": Perspectives of Experienced Secondary School Drama/ Theatre Students in Two Countries. NJ Drama Australia Journal, 34, 85 -I00.

Olsson, E.-K. 2006. Att vara någon annan. Teater som estetisk läroprocess vid tre 6-9-skolor. Växjö: Växjö universitet.

Remfeldt, J. 20I I. Att kalibrera den teaterpedagogiska kompassen. I E. Österlind (Red.) Drama - ledarskap som spelar roll (s. I69I 83). Lund: Studentlitteratur.

Skolverket 1998. Läroplan för förskolan. Reviderad 2016.

Skolverket, 20II. Läroplan för grundskolan, förskoleklassen och fritidshemmet.

SOU 2008:27. Framtidsuägen - en reformerad gymnasieskola. Stockholm: Utbildningsdepartementet.

SOU 2016:77. En gymnasieutbildning för alla. Stockholm: Utbildningsdepartementet.

Selander, S. \& Kress, G. R. 20Io. Design för lärande: ett multimodalt perspektiv. Stockholm: Norstedt.

Thorgersen, K. A. 2007. Unspoken truths: about aesthetics in Swedish schools. Licentiate Thesis. Piteå: Dept. of Music and Media. Luleå: Luleå University of Technology. 
Törnquist, E.-M. 20II. Estetiska lärprocesser. I S. Person \& B. Riddarsporre (Red.). Utbildningsvetenskap för grundskolans tidiga år. Stockholm: Natur \& Kultur.

Veiden, P. 20I 2. Tiden og den organisert (vel)vilje. I Ø.Varkøy, (Red.) Om nytte og unytte. Oslo: Abstrakt forlag.

Winner, E., Goldstein, T. \& Vincent-Lancrin, S. 20I3. Art for Art's Sake? The Impact of Arts Education. OECD Publishing (http:// dx.doi.org/IO.I787/9789264I80789-en).

Österlind, E. 2008. Gymnasieskolans projektarbete ur elevperspektiv. SKIP forskningsrapport $\mathrm{nr}$ 6. Stockholm: Stockholms universitets förlag. $93 \mathrm{~s}$.

Österlind, E. 20 I I. 'What Theatre is All About'. Students' Experiences of the Swedish Theatre Arts Program. Youth Theatre Journal 25(I), $75-86$.

Österlind, E., Østern, A.-L. \& Thorkelsdóttir, R. B. 20I6. Drama and theatre in a Nordic curriculum perspective - a challenged arts subject used as a learning medium in compulsory education. RiDE: The Journal of Applied Theatre and Performance 2I(I), 42-56. 